\title{
Sigurnosno osjetljivi podaci država članica u praksi Suda Europske unije
}

\section{Stjepan Novak}

\author{
https://doi.org/10.31297/hkju.21.1.5 \\ UDK 681.3:35.083.8(4)EU \\ 342.738:681.3(4)EU \\ 342.738:341.645(4)EU \\ Review scientific paper / pregledni znanstveni rad \\ Received / primljeno: 19.10.2020. \\ Accepted/prihvaćeno: 15. 1.2020.
}

Praksa Suda EU-a nije pratila normativnu izdvojenost koncepta nacionalne sigurnosti u odnosu na pravo Europske unije. Sud EU-a tim se pitanjem bavio prvo posredno, a zatim izravno, balansirajući interese nacionalnih sigurnosti država članica s jedne strane te prava koja jamči pravni sustav Europske unije s druge. Važan je zaključak prakse Suda EU-a u takvim slučajevima bio da činjenica da se neka odluka tiče nacionalne sigurnosti države članice ne dovodi sama po sebi do neprimjene prava Europske unije. Najnovijom praksom Sud EU-a prekoračio je dodijeljene mu ovlasti te lišio učinka treću rečenicu čl. 4/2. UEU-a prema kojoj nacionalna sigurnost posebice ostaje isključiva odgovornost svake države članice. Umjesto da se vodio praksom ESLJP-a i postavio određene uvjete nacionalnim

"Dr. sc. Stjepan Novak, Ministarstvo unutarnjih poslova Republike Hrvatske, Zagreb, Hrvatska (Ministry of the Interior of the Republic of Croatia, Zagreb, Croatia, e-mail: stjepannovak@hotmail.com). Mišljenja i stavovi izraženi u radu autorova su osobna mišljenja i ne predstavljaju stav institucije u kojoj radi.

ORCID ID: https://orcid.org/0000-0002-6600-4974 
zakonodavstvima koja uređuju prikupljanje podataka i postupanja sigurnosnih služba, Sud EU-a praktički je onemogućio učinkovito izvršavanje obveza država članica u vezi s očuvanjem nacionalne sigurnosti.

Ključne riječi: nacionalna sigurnost, nacionalni propisi, čl. 4/2. Ugovora o Europskoj uniji, praksa Suda EU-a, zadrŽavanje podataka

\section{Uvod}

U ovom radu analizirat će se odnos Suda Europske unije (dalje u tekstu: Sud EU-a) prema konceptu nacionalne sigurnosti država članica, odnosno prema ovlasti svake države da prikuplja i posebno štiti podatke koje smatra posebno važnima s aspekta svoje nacionalne sigurnosti, točnije sigurnosno osjetljive podatke. O toj problematici nema mnogo domaće ni strane stručne literature, a nije bogata ni praksa Suda EU-a. Međutim, kako će se pokazati u ovom radu, svojom je proaktivnom praksom Sud EU-a počeo zadirati u područje nacionalne sigurnosti (Celeste, 2019, str. 155) s obzirom na to da će se često područja "pokrivena“ pravom Europske unije preklapati s područjem nacionalne sigurnosti u navedenom smislu. To preklapanje posljedica je činjenice da sama normativna izdvojenost tog koncepta iz pravnog sustava Europske unije ne znači i njegovu potpunu izoliranost od tog sustava. U analizi te problematike od presudne su važnosti odredba čl. 4/2. Ugovora o Europskoj uniji ${ }^{1}$ (dalje u tekstu: UEU) i odredba čl. 346/1. Ugovora o funkcioniranju Europske unije ${ }^{2}$ (dalje u tekstu: UFEU).

Iz obiju odredaba proizlazi izdvojenost koncepta nacionalne sigurnosti iz dosega prava Europske unije. Takva izdvojenost do izražaja je dolazila i u sekundarnim pravnim izvorima Europske unije. ${ }^{3}$ Tako se, na primjer,

${ }^{1}$ Čl. 4/2. UEU-a u trećoj rečenici propisuje da nacionalna sigurnost posebice ostaje isključiva odgovornost svake države članice.

2 Čl. 346/1. UFEU-a propisuje da odredbe UEU-a i UFEU-a ni u kojem slučaju ne mogu isključiti primjenu sljedećih pravila: a) nijedna država članica nije obvezna davati informacije ako smatra da bi njihovo otkrivanje bilo suprotno osnovnim interesima njezine sigurnosti te b) svaka država članica može poduzeti one mjere koje smatra potrebnima za zaštitu osnovnih interesa svoje sigurnosti, koje su povezane s proizvodnjom ili trgovinom oružjem, streljivom i ratnom opremom.

${ }^{3}$ Vidi npr. čl. 24. Direktive Vijeća 2004/83/EZ od 29. travnja 2004., čl. 16. Uredbe 2016/679 Europskog parlamenta i Vijeća od 27. travnja 2016., čl. 15. Direktive (EU) 
u tzv. Direktivi o zadržavanju podataka 2006/24/EZ u t. 4. preambule pojašnjavao čl. 15. Direktive o privatnosti i elektroničkim komunikacijama te je konstatirano da "svako takvo ograničenje u demokratskom društvu mora biti nužno, prikladno i razmjerno za posebne potrebe očuvanja javnog reda, tj. za zaštitu nacionalne sigurnosti (tj. državne sigurnosti), obrane, javne sigurnosti ili sprečavanje, istragu, otkrivanje i progon kaznenih djela ili neovlaštene uporabe sustava elektroničke komunikacije“. ${ }^{4}$ Slične odredbe sadržavaju i Direktiva 2000/31/EZ, ${ }^{5}$ 2013/33/EU, ${ }^{6}$ Direktiva 2008/115/EZ ${ }^{7}$ itd.

Ipak, unatoč normativnoj izdvojenosti koncepta nacionalne sigurnosti iz pravnog sustava Europske unije, odnos tog sustava prema navedenom pojmu mijenjao se praksom Suda EU-a.

Cilj je ovoga rada istražiti razvoj odnosa Suda EU-a prema sigurnosno osjetljivim podacima država članica kao važnom segmentu njihovih nacionalnih sigurnosti. U tom kontekstu u radu će se pokušati odgovoriti na pitanje je li svojom najnovijom praksom Sud EU-a prekoračio dodijeljene mu ovlasti te lišio učinka treću rečenicu čl. 4/2. UEU-a prema kojoj nacionalna sigurnost ostaje isključiva odgovornost svake države članice. Ta praksa, naime, dovodi u pitanje ovlast država članica da uređuju postupanje svojih nadležnih tijela kada je riječ o prikupljanju podataka koje one smatraju posebno važnima s aspekta svojih nacionalnih sigurnosti.

U opisanom smislu, u drugom će se poglavlju komparativnom metodom prikazati kako je pojam nacionalne sigurnosti određen u domaćem i poredbenom pravu. Treće poglavlje podijeljeno je u tri dijela. U prvom dijelu analizirat će se praksa Suda EU-a u kojoj se koncept nacionalne sigurnosti obrađivao tek posredno, u drugom praksa tog Suda koja se izravno odnosila na čl. 346. UFEU-a, a u trećem najnovija praksa Suda EU-a koja se izravno odnosila na treću rečenicu čl. 4/2. UEU-a. Pritom će se upotrebljavati kazuistička, odnosno empirijska metoda.

Na kraju će se iznijeti zaključna razmatranja.

2016/680 Europskog parlamenta i Vijeća od 27. 4. 2016. i čl. 15. Direktive 2002/58/EZ Europskog parlamenta i Vijeća od 12. srpnja 2002.

${ }^{4}$ Direktiva 2006/24/EZ Europskog parlamenta i Vijeća od 15. ožujka 2006.

${ }^{5}$ Direktiva 2000/31/EZ Europskog parlamenta i Vijeća od 8. lipnja 2000.

${ }^{6}$ Direktiva 2013/33/EU Europskog parlamenta i Vijeća od 26. lipnja 2013.

${ }^{7}$ Direktiva 2008/115/EZ Europskog parlamenta i Vijeća od 16. prosinca 2008. 


\section{Nacionalna sigurnost u pravnom sustavu Hrvatske i poredbenom pravu}

U hrvatskome pravnom sustavu ne postoji jedinstvena i općenita definicija pojma nacionalne sigurnosti (Lacković, 2000, str. 197, 198; Cvrtila, 1995, str. 66) kao ni u većini država članica Europske unije. ${ }^{8}$ Iznimke su, primjerice, Rumunjska, Španjolska i Slovenija.

Člankom 1. Zakona o nacionalnoj sigurnosti Rumunjske nacionalna sigurnost definirana je kao stanje socijalne, gospodarske i političke zakonitosti, ravnoteže i stabilnosti potrebne za postojanje i razvoj rumunjske nacionalne države - suverene, jedinstvene, neovisne i nedjeljive države $s$ ciljem održavanja pravnog poretka kao i okružja za nesmetano ostvarivanje temeljnih prava, sloboda i dužnosti građana u skladu s demokratskim načelima i pravima sadržanim u Ustavu. ${ }^{9}$

Slično i španjolski Zakon o nacionalnoj sigurnosti u čl. 7/1. daje definiciju nacionalne sigurnosti kao djelovanja države s ciljem zaštite slobode i dobrobiti njezinih građana, osiguranja obrane Španjolske i njezinih ustavnih načela i vrijednosti kao i, zajedno s partnerima i saveznicima, davanja doprinosa međunarodnoj sigurnosti ispunjavanjem preuzetih obveza. ${ }^{10}$

U Rezoluciji o izvorišnim osnovama nacionalne sigurnosti Republike Slovenije iz 1993. nacionalna sigurnost Republike Slovenije definirana je kao stanje u kojem se ostvaruje zaštita ljudskih prava i temeljnih sloboda, uravnotežen gospodarski, socijalni i kulturni razvoj te ostvarivanje drugih životnih interesa, djelovanje demokratske, pravne, suverene i teritorijalno jedinstvene i nedjeljive države Republike Slovenije (Tatalović, 1997, str. 82).

Ipak, većina nacionalnih zakonodavstava koja se odnosi na nacionalnu sigurnost usredotočenija je na pojedine njezine segmente ili na određivanje njezinih ciljeva i djelovanja nego na njezino definiranje. Tako, primjerice, grčki Zakon 3649/2008 u čl. 2. navodi da je djelovanje nacionalne obavještajne službe: a) zaštita i promicanje političkog, gospodarskog, vojnog i cjelokupnog nacionalnog strateškog interesa države, b) sprečavanje i

${ }^{8}$ European Parliament, Directorate General for internal policies, Policy Department C: Citizens' Rights adn Constitutional Affairs: „National security and secret evidence in legislation and before the courts: exploring the challenges", Study for the LIBE Commitee, 10. 12. 2014., str. 7.

9 The Law No.51/July 29, 1991 on the National Security of Romania.

10 Ley 36/2015, de 28 de septiembre, de Seguridad National. 
borba protiv djelatnosti koje su prijetnja demokraciji, temeljnim pravima, teritorijalnoj cjelovitosti i nacionalnoj sigurnosti Grčke kao i blagostanju nacije, c) sprečavanje i borba protiv djelatnosti terorističkih organizacija i drugih zločinačkih organizacija. ${ }^{11}$

Litavski Zakon o osnovama nacionalne sigurnosti u čl. 1/2. navodi razvoj i jačanje demokracije, osiguravanje sigurnog postojanja nacije i države, odvraćanje svih potencijalnih agresora te očuvanje teritorijalnog integriteta i ustavnog poretka države kao ciljeve nacionalne sigurnosne politike. ${ }^{12}$

U pravnom sustavu Republike Hrvatske Zakon o sigurnosno-obavještajnom sustavu Republike Hrvatske u čl. 1. određuje da se tim zakonom „radi sustavnog prikupljanja, analize, obrade i ocjene podataka koji su od značaja za nacionalnu sigurnost, u cilju otkrivanja i sprečavanja radnji pojedinaca ili skupina koje su usmjerene: protiv opstojnosti, neovisnosti, jedinstvenosti i suvereniteta Republike Hrvatske, nasilnom rušenju ustroja državne vlasti, ugrožavanju Ustavom Republike Hrvatske i zakonima utvrđenih ljudskih prava i temeljnih sloboda te osnova gospodarskog sustava Republike Hrvatske i koji su nužni za donošenje odluka značajnih za ostvarivanje nacionalnih interesa u području nacionalne sigurnosti, osnivaju sigurnosno-obavještajne agencije. " ${ }^{13}$

Kako pokazuju navedeni primjeri, definicije nacionalnih sigurnosti odnose se na ciljeve, odnosno zadatke tijela zaduženih za nacionalnu sigurnost. Ti će se ciljevi uvijek odnositi na zaštitu temeljnih vrijednosti pojedine države. S obzirom na to, interes države da bude isključiva donositeljica odluka kada je riječ o njezinoj nacionalnoj sigurnosti, što uključuje i modalitete njezine zaštite, prepoznat je i na razini Europske unije.

\section{Nacionalna sigurnost u pravnom sustavu Europske unije u praksi Suda EU-a}

Kada se govori o nacionalnoj sigurnosti, potrebno ju je razlikovati od pojma javne sigurnosti. Člankom 27/1. Direktive o pravu građana Unije i članova njihovih obitelji na slobodno kretanje i boravište na području dr-

11 Law number 3649, National Intelligence Service and other provisions.

12 Republic of Lithuania Law on the basics of national security of Lithuania. $105 / 06$

13 Zakon o sigurnosno-obavještajnom sustavu Republike Hrvatske, NN 79/06, 
žave članice propisano je da u skladu s odredbama iz iste Direktive države članice mogu ograničiti slobodu kretanja i boravišta građanima Unije i članovima njihovih obitelji bez obzira na njihovo državljanstvo sa svrhom zaštite javnog poretka, javne sigurnosti ili javnog zdravlja. S tim u vezi, koncepte ,javne sigurnosti“ i „osobnog ponašanja pojedinca“ tumačio je i Sud EU-a u predmetima kao što su Van Duyn, ${ }^{14}$ Bonsignore, ${ }^{15}$ Olazabal ${ }^{16}$ ili Tsakouridis gdje je konstatirao da pojam ,javne sigurnosti“ iz čl. 24/1. Direktive o pravu građana Unije i članova njihovih obitelji na slobodno kretanje i boravište na području države članice pokriva i unutarnju sigurnost države članice i njezinu vanjsku sigurnost. ${ }^{17}$

U starijoj literaturi pojam „javne sigurnosti“ definira se kao „osiguranje reda i poštivanje zakonitosti, suzbijanje kriminala i terorizma" (Nobilo, 1988, str. 69).

S druge strane, pojam „nacionalne sigurnosti“ može se definirati kao „složena interakcija političkih, ekonomskih, vojnih, ideoloških, pravnih, socijalnih i drugih unutrašnjih i vanjskih društvenih faktora kroz koju pojedine države nastoje osigurati normalne, tj. prihvatljive uvjete očuvanja suvereniteta, teritorijalnog integriteta, fizičkog opstanka stanovništva, političku nezavisnost i mogućnost za ravnopravan, skladan i brz društveni razvoj." (Nobilo, 1988, str. 73).

Uzimajući takvu definiciju u obzir, razumljivo je nastojanje svake države članice da nacionalna sigurnost ostane njezina isključiva odgovornost, o čemu svjedoči i citirana odredba čl. 4/2. UEU-a. Slijedom toga, razumljivo je i da Sud EU-a u prijašnjim razdobljima nije imao ni potrebe ni prigode očitovati se o tom konceptu, osim neposredno, dajući tako i vlastite definicije tog koncepta.

Tako je, primjerice, u presudi $H$. T. ustvrdio da pojam „neotklonjivi razlozi nacionalne sigurnosti ili javnog reda" iz Direktive 2004/83/EZ ${ }^{18}$ pretpostavlja ne samo postojanje štete za javnu sigurnost nego i to da je takva

14 Presuda od 4. 12. 1974., Yvonne van Duyn v. Home Office, C-41/74, ECLI: ECLI:EU:C:1974:133.

15 Presuda od 26. 2. 1975., Carmelo Angelo Bonsignore v. Oberstadtdirektor der Stadt Köln, C-67/74, ECLI: ECLI:EU:C:1975:34.

16 Presuda od 26. 11. 2002., Ministre de l'Intérieur protiv Aitor Oteiza Olazabal, C-100/01, ECLI:EU:C:2002:712.

17 Presuda od 23. 11. 2010., Land Baden-Württemberg v. Panagiotis Tsakouridis, C-145/09, EU:C:2010:708, para 43. Vidi i presudu od 24. 6. 2015., H. T. protiv Land Baden-Württemberg, C-373/13, ECLI:EU:C:2015:413 (H. T.), para 78.

18 Čl. 24. Direktive Vijeća 2004/83/EZ od 29. travnja 2004. 
šteta posebno visok stupanj ozbiljnosti koji se ogleda u upotrebi izraza „neotklonjivi razlozi“ nacionalne sigurnosti. ${ }^{19} \mathrm{U}$ predmetu J. N. Sud EU-a konstatirao je da ugrožavanje nacionalne sigurnosti, s obzirom na zahtjev nužnosti, može opravdati zadržavanje ili nastavak zadržavanja podnositelja zahtjeva za međunarodnu zaštitu samo pod uvjetom da je njegovo osobno ponašanje stvarna, trenutačna i dovoljno ozbiljna prijetnja koja ugrožava temeljni interes društva, odnosno unutarnju ili vanjsku sigurnost dotične države članice. ${ }^{20}$

Razvoj odnosa nacionalne sigurnosti i prava Europske unije moguće je promatrati s obzirom na dva načina na koja se Sud EU-a bavio konceptom nacionalnih sigurnosti država članica u svojoj praksi. Iako su se ta dva tipa prakse vremenski poklapala, načelno možemo konstatirati da je do izravnijeg bavljenja konceptom nacionalne sigurnosti od Suda EU-a došlo nešto kasnije u odnosu na neizravne analize tog koncepta od istog Suda. U tom smislu, analizirat ćemo praksu Suda EU-a u dvjema fazama: fazi neizravnog sukobljavanja nacionalnih sigurnosti država članica i prava Europske unije te fazi izravnog sukobljavanja nacionalnih sigurnosti država članica i prava Europske unije. Nakon tih dviju faza uslijedio je konačni obračun Suda EU-a s nacionalnim sigurnostima država članica.

\subsection{Faza neizravnog sukobljavanja nacionalnih sigurnosti država članica i prava Europske unije}

Sud EU-a uvažavao je elemente nacionalnih identiteta država članica kao odraz njihovih ustavnih poredaka (Cloots, 2015, str. 7) prije stupanja na snagu Lisabonskog ugovora kao i nakon toga. U predmetima Sayn-Wittgenstein, ${ }^{21}$ Runevič-Vardyn ${ }^{22}$ i Bogendorff von Wolffersdorff ${ }^{23}$ Sud EU-a smatrao je da određeni aspekti prava Europske unije trebaju ustuknuti pred nacionalnim identitetima. Konkretno, riječ je bila o statusu

19 H. T., para 78.

20 Presuda od 15. 2. 2016., J. N. protiv Staatssecretaris van Veiligheid en Justitie, C-601/15, ECLI:EU:C:2016:84 (J. N.), para 67.

21 Presuda od 22. 12. 2010., Ilonka Sayn-Wittgenstein protiv Landeshauptmann von Wien, C-208/09, ECLI:EU:C:2010:806 (Sayn-Wittgenstein).

22 Presuda od 12. 5. 2011., Malgožata Runevič-Vardyn i Łukasz Pawet Wardyn protiv Vilniaus miesto savivaldybes administracija $i$ dr., C-391/09, ECLI:EU:C:2011:291 (Runevič-Vardyn).

23 Presuda od 2. 6. 2014., Nabiel Peter Bogendorff von Wolffersdorff protiv Standesamt der Stadt Karlsrube i Zentraler Juristischer Dienst der Stadt Karlsrube, C-438/14, ECLI:EU:C:2016:401 (Bogendorff von Wolffersdorff). 
republike, ${ }^{24}$ odnosno o nacionalnom jeziku. ${ }^{25} \mathrm{~S}$ druge strane, relevantne belgijske ustavne odredbe o podjeli ovlasti između flamanske vlade i savezne vlade (Rodin, 2011, str. 21) ${ }^{26}$ ili odredbe grčkog Ustava, koje su bez iznimke zabranjivale vlasnicima, glavnim dioničarima i upraviteljima medijskih trgovačkih društava sudjelovanje u ugovorima o javnim radovima (Besselink, 2010, str. 48), nisu dobile takav položaj. Rodin u tom smislu razlikuje „velike" i „male" slučajeve nacionalnog identiteta (Rodin, 2011, str. 39). Slično, i Besselink navodi da se trivijalnim odredbama ustavnog prava neće dati prednost pred pravom Europske unije (Besselink, 2010, str. 49).

Pitanje nacionalne sigurnosti u praksi Suda EU-a pojavljivalo se u početku tek posredno. Sud EU-a tim se pitanjem bavio u odnosu na zaštitu podataka koje su države članice klasificirale odgovarajućim stupnjem tajnosti u skladu s vlastitim zakonodavstvom balansirajući interese nacionalnih sigurnosti država članica s jedne strane te prava osoba prema kojima su primijenjene sankcije na temelju upravo tih podataka s druge.

U tom smislu, u presudi OMPI I Opći je sud zaključio da na pitanje trebaju li navodno povjerljivi podaci i dokazi biti dostavljeni samo sudu ili i tužiteljima u postupku, odnosno osobama na koje se sankcije odnose i njihovim zastupnicima, treba odgovoriti da treba voditi računa i o interesima javne sigurnosti i o interesima pravne zaštite stranaka. ${ }^{27}$ Pritom se Opći sud pozivao i na praksu Europskog suda za ljudska prava (dalje u tekstu: ESLJP) iz predmeta Chahal protiv Ujedinjenog Kraljevstva ${ }^{28}$ u kojem je ESLJP istaknuo da nacionalne vlasti nisu izuzete od svakog nadzora nacionalnih sudova samo zato što se pozivaju na argument da se slučaj tiče nacionalne sigurnosti i terorizma.

$S$ tim u vezi, u predmetima $Z Z^{29}$ i Kadi IV ${ }^{30}$ Sud EU-a dao je posebne upute nacionalnim sudovima (Koutrakos, 2016, str. 204). Ako se nacionalna vlast poziva na to da bi nacionalna sigurnost bila ugrožena preciznim i

24 Sayn-Wittgenstein, para 83. i 91. - 93. Slično i Bogendorff von Wolffersdorff, para 73.

25 Runevič-Vardyn, para 85. i 86.

26 Presuda od 1. 4. 2008., Vlada Communauté française $i$ Gouvernement wallon protiv Gouvernement flamand, C-212/06, ECLI:EU:C:2008:178, para 57. i 58.

27 Presuda od 12. 12. 2006., Organisation des Modjahedines du people d'Iran protiv Vijeća Europske unije, T-228/02 ECLI:EU:T:2006:384 (OMPI I), para 132. - 137. i 156. - 158.

${ }^{28}$ V. predmet Chabal protiv Ujedinjenog Kraljevstva [VV], br. 22414/93 od 15. 11. 1996. (Chahal protiv Ujedinjenog Kraljevstva).

29 Presuda od 4. 6. 2013., ZZ protiv Secretary of State for the Home Department, C-300/11 ECLI:EU:C:2013:363 (ZZ).

30 Presuda od 18. 7. 2013., Europska komisija i dr. protiv Yassin Abdullab Kadi, spojeni predmeti C-584/10 P, C-593/10 P i C-595/10 P, ECLI:EU:C:2013:518 (Kadi IV), para 120. -129 . 
potpunim obavještavanjem zainteresirane osobe o razlozima na kojima se temelji odluka koja se na nju odnosi, ona to mora i dokazati. Ne uspije li, a po pozivu suda ne priopći te razloge, odnosno podatke, nacionalni će sud odluku donijeti ne uzimajući ih u obzir. Uspije li nacionalna vlast dokazati opasnost za interese nacionalne sigurnosti, tada nacionalni sud mora pronaći način kojim se postiže odgovarajuća ravnoteža između zahtjeva nacionalne sigurnosti i zahtjeva prava na učinkovitu sudsku zaštitu, ograničavajući potonje pravo samo onoliko koliko je to strogo nužno. ${ }^{31}$

I u predmetu $D^{32}$ nacionalna sigurnost bila je posredno podvrgnuta testu proporcionalnosti. Sud EU-a ustvrdio je da pravu Europske unije nije suprotno nacionalno pravo koje predviđa automatski prestanak radnog odnosa pilota zaposlenih u društvu koje se koristi zrakoplovima u okviru aktivnosti u vezi sa zaštitom nacionalne sigurnosti države članice kada navrše 60 godina ako je ono proporcionalno, odnosno nužno za javnu sigurnost. ${ }^{33}$ Direktiva 2000/78 $8^{34}$ o kojoj je bila riječ nije sadržavala izraz „nacionalna sigurnost“, već samo ,javna sigurnost“, no Sud EU-a izričito je ustvrdio da kada je u konkretnom slučaju riječ o cilju koji se odnosi na zaštitu nacionalne sigurnosti, mjere kojima se nastoji osigurati provedba i nesmetano provođenje aktivnosti $\mathrm{u}$ interesu nacionalne sigurnosti također su mjere kojima se osigurava javna sigurnost u smislu relevantnih odredbi Direktive. ${ }^{35}$ Čl. 4/2. nije se ni spomenuo u cijeloj presudi. Očito Sud EU-a nije smatrao da je riječ o materiji koja posebice ostaje u isključivoj nadležnosti država članica iako je i sam konstatirao da je osporavani nacionalni propis imao u cilju upravo zaštitu nacionalne sigurnosti.

U ovom kontekstu važno je spomenuti i slučajeve Digital Rights Ireland ${ }^{36}$ te Tele2 $i$ Watson. ${ }^{37}$

31 ZZ, para 58. -68 .

32 Presuda od 7. 11. 2019., Gennaro Cafaro protiv DQ, C-396/18, ECLI:EU:C:2019:929 $(\mathrm{DQ})$.

${ }^{33} \mathrm{DQ}$, para 72. U tom smislu vidi i predmet J. N., para 56.

34 Direktiva Vijeća 2000/78/EZ od 27. studenoga 2000. o uspostavi općeg okvira za jednako postupanje pri zapošljavanju i obavljanju zanimanja, dostupno na https://eur-lex. europa.eu/legal-content/HR/TXT/PDF/?uri=CELEX:32000L0078\&from=EN.

${ }^{35} \mathrm{DQ}$, para 48.

36 Presuda od 8. 4. 2014., Digital Rights Ireland Ltd protiv Minister for Communications, Marine and Natural Resources $i$ dr. i Kärntner Landesregierung $i d r$., C-293/12 i C-594/12, ECLI:EU:C:2014:238 (Digital Rights Ireland).

37 Presuda od 21. 12. 2016., Tele2 Sverige AB protiv Post- och telestyrelsen i Secretary of State for the Home Department protiv Toma Watsona, Petera Bricea $i$ Geoffreyja Lewisa, C-203/15 i 698/15, ECLI:EU:C:2016:970 (Tele2 $i$ Watson). 
Cilj Direktive o zadržavanju podataka, koja je bila predmet presude $D i$ gital Rights Ireland, u skladu s čl. 1/1. bio je ,uskladiti odredbe država članica koje se odnose na obveze pružatelja javno dostupnih elektroničkih komunikacijskih usluga ili javnih komunikacijskih mreža u odnosu na zadržavanje određenih podataka koje skupljaju ili obrađuju pružatelji kako bi se osiguralo da ti podaci budu dostupni u istrazi, otkrivanju i progonu teških kaznenih djela, kako je određeno nacionalnim zakonodavstvom svake države članice." ${ }^{38}$

Nadležni nacionalni sudovi u Irskoj i Austriji, u povodu postupaka koji su se vodili na njima, postavili su Sudu EU-a prethodna pitanja koja su se svodila na ispitivanje valjanosti predmetne Direktive. Sud EU-a je, spojivši ta dva predmeta, zaključio da je zadržavanje podataka o telefonskom i internetskom prometu podataka praktički svih korisnika unutar Europske unije neproporcionalna mjera za ostvarivanje cilja javne sigurnosti (von Danwitz, 2014, str. 1332). ${ }^{39}$

Presuda Digital Rights Ireland ubrzo je dobila svoj nastavak u presudi Tele2 $i$ Watson, koja se odnosila na nacionalna zakonodavstva država članica. Sud EU-a odgovarao je na pitanje ,jesu li nacionalna pravila koja pružateljima elektroničkih komunikacijskih usluga nameću opću obvezu zadržavanja podataka i koja propisuju pristup nadležnih nacionalnih tijela zadržanim podacima a da, među ostalim, ne ograniče svrhu tog pristupa na borbu protiv teških kaznenih djela i ne podvrgnu pristup prethodnom nadzoru suda ili nezavisnog upravnog tijela, u skladu s pravom Unije". ${ }^{40}$

Baveći se općom obvezom zadržavanja podataka, Sud EU-a naveo je da, prema nacionalnom zakonu o kojem je riječ, podaci koje pružatelji elektroničkih komunikacijskih usluga trebaju zadržati omogućavaju pronalaženje i identifikaciju izvora komunikacije i njezina odredišta, utvrđivanje datuma, vremena, trajanja i vrste komunikacije, pronalaženje i identifikaciju komunikacijske opreme korisnikâ kao i otkrivanje lokacije mobilne komunikacijske opreme, zatim ime i adresu pretplatnika ili registriranog korisnika, broj telefona pozivatelja i pozvani broj kao i IP adresu za internetske usluge. Na taj način oni omogućavaju saznanja s kojom je osobom pretplatnik ili registrirani korisnik komunicirao, upotrebom kojeg sredstva, koliko je dugo ta komunikacija trajala kao i na kojem se mjestu ona događala. Kao i u presudi Digital Rights Ireland, naveo je da oni omoguća-

\footnotetext{
38 Direktiva o zadržavanju podataka, čl. 1.

39 Digital Rights Ireland, para 57. - 69.

40 Sud EU-a, Priopćenje za medije 145/16 od 21. 12. 2016.
} 
vaju i donošenje vrlo detaljnih podataka, odnosno zaključaka o privatnom životu osoba na koje se zadržani podaci odnose.

Ponovno se analogijom pozivajući na presudu Digital Rights Ireland, Sud EU-a istaknuo je i da nacionalni zakon o kojem je riječ zapravo obuhvaća sve osobe koje se koriste elektroničkim komunikacijskim uslugama neovisno o njihovoj povezanosti, odnosno nepovezanosti s teškim kaznenim djelima. Sud EU-a zaključuje da se takav nacionalni zakon ne može smatrati opravdanim u demokratskom društvu s obzirom na to da prelazi granice strogo nužnog te kao takav nije u skladu s pravom Europske unije. ${ }^{41}$ S aspekta nacionalne sigurnosti posebno je važno da je Sud EU-a naveo da se „u posebnim okolnostima, poput onih u kojima su terorističke aktivnosti prijetnja za vitalne interese nacionalne sigurnosti, obrane ili javne sigurnosti“ pristup podacima drugih osoba može odobriti kad postoje objektivni elementi koji omogućavaju zaključak da ti podaci u konkretnom slučaju mogu dati stvaran doprinos borbi protiv takvih aktivnosti. ${ }^{42}$ Sud EU-a također je naveo da je bitno da pristup nadležnih nacionalnih tijela zadržanim podacima u načelu, osim u valjano opravdanim hitnim slučajevima, bude podvrgnut prethodnom nadzoru suda ili neovisnoga upravnog tijela i da odluka tog suda ili tijela bude donesena nakon obrazloženog zahtjeva nacionalnih tijela. ${ }^{43}$

U skladu s prikazanom praksom, Sud EU-a ušao je u sferu pridržanu državama članicama na način da je i nacionalnu sigurnost posredno podvrgnuo procesu balansiranja u odnosu na pravo Europske unije.

S druge strane, u skladu s praksom Suda EU-a i u predmetima koji ulaze u isključivu nadležnost država članica, one moraju svoje ovlasti izvršavati u skladu s pravom Europske unije. ${ }^{44} \mathrm{U}$ već navedenom predmetu ZZ konstatirao je da sama činjenica da se neka odluka tiče državne sigurnosti države članice ne dovodi sama po sebi do neprimjene prava Europske unije (Stępkowski, 2016, str. 110). ${ }^{45}$

$\mathrm{S}$ tim u vezi postavilo se pitanje koji je zapravo stav Suda EU-a u odnosu na treću rečenicu čl. 4/2. UEU-a, odnosno u kojoj je mjeri nacionalna sigurnost pojedine države članice ipak pod utjecajem prava Europske unije.

41 Tele2 $i$ Watson, para 105. - 107. Usporediti s Digital Rights Ireland, para 57. - 59.

42 Tele2 $i$ Watson, para 119.

43 Tele2 $i$ Watson, para 120.

44 Vidi npr. presuda od 2. 3. 2010. Janko Rottman protiv Freistaat Bayern, C-135/08, ECLI:EU:C:2010:104.

$45 \mathrm{ZZ}$, para 38. 


\subsection{Faza izravnog sukobljavanja nacionalnih sigurnosti država članica i prava Europske unije}

U ovoj fazi Sud se, manje ili više izravno, bavio odredbama čl. 346/1. UFEU-a, odnosno konceptom nacionalne sigurnosti.

U predmetu Ellinika Sud EU-a naglasio je da, u skladu s čl. 346/1. t. b) UFEU-a, svaka država članica može poduzeti one mjere koje smatra potrebnima za zaštitu osnovnih interesa svoje sigurnosti, koje su povezane s proizvodnjom ili trgovinom oružjem, streljivom i ratnom opremom. U skladu s tom odredbom, takve mjere ne smiju štetno utjecati na uvjete tržišnog natjecanja na unutarnjem tržištu u odnosu na proizvode čija namjena nije specifično vojna. ${ }^{46}$

U predmetu Hellenic Shipyards Grčka se pozivala na čl. 346/1. t. b) UFEUa. Komisija je državne potpore uplaćene trgovačkom društvu Hellenic Shipyards, vlasniku grčkoga civilnog i vojnog brodogradilišta specijaliziranog za izgradnju vojnih brodova, odredila kao mjere nespojive s unutarnjim tržištem, slijedom čega je trebalo izvršiti njihov povrat. Grčka je tvrdila da bi potpun povrat predmetnih potpora mogao dovesti do njegova stečaja i time negativno utjecati na njegove vojne djelatnosti, a slijedom toga i na obrambene kapacitete Grčke te da postoji prikladnija mjera za likvidaciju navedenog društva kojom se uzimaju u obzir osnovni interesi sigurnosti navedene države članice u smislu čl. 346/1. t. b) UFEU-a. Primjer za to njegovo je podvrgavanje posebnoj upravi. Sud EU-a taj je argument odbio s obzirom na to da Grčka nije ni prije poduzimala prikladnije mjere na koje se pozivala, ali nije osporio samu mogućnost države da se poziva na svoje osnovne interese sigurnosti u smislu navedene odredbe. Štoviše, Sud EU-a izrijekom je ostavio takvu mogućnost otvorenom. ${ }^{47}$

U presudi Europska komisija protiv Republike Austrije Sud EU-a taj je zaključak analogijom prenio i na odredbu čl. 346/1. t. a) koja određuje da nijedna država članica nije obvezna davati informacije ako smatra da bi njihovo otkrivanje bilo suprotno osnovnim interesima njezine sigurnosti. ${ }^{48}$ U konkretnom slučaju austrijsko je zakonodavstvo obvezivalo javne naru-

46 Presuda od 28. 3. 2013., Ellinika Nafpigeia AE protiv Europske komisije, C-246/12 P, ECLI:EU:C:2013:133, para 25.

47 Presuda od 14. 11. 2018., Europska komisija protiv Helenske Republike, C-93/17, ECLI:EU:C:2018:903, para 1., 8., 9., 13., 88. - 90.

48 Presuda od 20. 3. 2018., Europska komisija protiv Republike Austrije, C-187/16, ECLI:EU:C:2018:194 (Europska komisija protiv Republike Austrije), para 78. 
čitelje da ugovore o uslugama za izradu putovnica i sličnih dokumenata izravno, bez provođenja javne nabave, dodijele konkretnomu trgovačkom društvu pozivajući se pritom i na spomenutu odredbu. Austrija je naglašavala da je sigurnosna politika svake države bitan element njezina državnog suvereniteta te da je na državama članicama da definiraju svoje osnovne interese sigurnosti i odrede jesu li nužne sigurnosne mjere s obzirom na to da u vezi s tim raspolažu širokom diskrecijskom ovlašću. ${ }^{49}$ Pri donošenju odluke Sud EU-a vodio se i Mišljenjem nezavisne odvjetnice Kokkot koja je naglasila da će Sud EU-a „pojasniti prostor koji je državama članicama prepušten radi odstupanja od prava Unije kada se pozivaju na osnovne interese svoje nacionalne sigurnosti navedene u čl. 346/1. UFEU-a". ${ }^{50}$

Sud EU-a konstatirao je da mjere koje države članice donose u okviru legitimnih zahtjeva nacionalnog interesa nisu u cijelosti podvrgnute primjeni prava Unije samo zbog toga što se njima zadire, među ostalim, $u$ interes javne sigurnosti ${ }^{51}$ te je nakon detaljne analize ustvrdio da je nepoštovanje postupaka javne nabave propisanih navedenim direktivama neproporcionalno u odnosu na cilj koji je isticala Austrija. Drugim riječima, zaključio je da Republika Austrija nije dokazala da se cilj koji se sastoji od sprečavanja otkrivanja osjetljivih podataka koji se odnose na izradu službenih isprava o kojima je riječ nije mogao postići u okviru natjecanja, poput onoga propisanog relevantnim direktivama. ${ }^{52}$

Jedan od austrijskih argumenata bio je i da postoji rizik da će se sigurnosno osjetljivi, odnosno klasificirani podaci otkriti ako poduzetnici sa sjedištem izvan Austrije ne budu mogli „potpuno izbjeći intervenciju tijela svoje odnosne države članice jer su u određenim slučajevima sami dužni, na temelju odredbi primjenjivih u tim državama, surađivati s tim tijelima ili obavještajnim službama navedenih država, i to čak i kada izvršavaju ugovore o javnoj nabavi iz podružnice koja se nalazi u Austriji“. Sud je istaknuo da ,austrijska tijela, radi provedbe ugovora o kojima je riječ, u uvjete kojima se uređuje javna nabava mogu unijeti ugovorne odredbe

49 Europska komisija protiv Republike Austrije, para 56. i 57. Vidi i presudu od 30. 9. 2003., Fiocchi Munizioni, T-26/01, ECLI:EU:T:2003:248, para 58.

50 Mišljenje od 20. 7. 2017., Europska komisija protiv Republike Austrije, C-187/16, ECLI:EU:C:2017:578, para 4.

51 Europska komisija protiv Republike Austrije, para 76. V. i presudu od 8. 4. 2008., Komisija Europskib zajednica protiv Talijanske Republike, C-337/05, ECLI:EU:C:2008:203, para 42. i presudu od 11. 3. 2003., Alexander Dory protiv Bundesrepublik Deutschland, C-186/01, ECLI:EU:C:2003:146, para 30.

52 Europska komisija protiv Republike Austrije, para 94. i 95. 
kojima se ponuditelj obvezuje na opću povjerljivost i propisati da će poduzetnik natjecatelj koji osobito zbog zakonodavstva svoje države članice ne može ponuditi dostatna jamstva u pogledu te obveze s obzirom na tijela te države biti isključen iz postupka dodjele. Austrijska tijela također mogu propisati primjenu sankcija na ponuditelja, osobito ugovornih, u slučaju nepoštovanja takve obveze tijekom provedbe ugovora o kojem je riječ." ${ }^{53}$ Smatram da odgovor Suda EU-a na argument Austrije nije realan. Prijedlozi Suda EU-a o načinu zaštite podataka Austrije nisu takvi da bi mogli uroditi plodom. Nikakve ugovorne odredbe ne mogu pobiti glavni argument i najveću austrijsku bojazan, a to je da će poduzetnici izvan Austrije biti pod utjecajem nadležnih tijela svojih država koja će možebitno pokušati doći do tih podataka te, ako žele, vjerojatno u tome i uspjeti. Sud EU-a predložio je i da se u ugovor uvrsti odredba o isključenju iz postupka poduzetnika koji ne može ponuditi dostatna jamstva u vezi s obvezom zaštite klasificiranih podataka u odnosu na nadležna tijela njegove države. Takva odredba, u slučaju iskrena odgovora, značila bi izuzeće svakog poduzetnika koji sjedište ima izvan Austrije te bi bila zaobilaženje propisa Europske unije o kojima je u konkretnom slučaju riječ s obzirom na to da takva jamstva nijedan poduzetnik ne može dati. Čak i kad bi koji poduzetnik dao takvo jamstvo, Austrija ne može znati hoće li ga se uistinu i pridržavati s obzirom na to da će i njihovi odnosi i kontakti s nacionalnim tijelima vjerojatno biti klasificirani. Konačno, konkretni poduzetnik može procijeniti da će korist od podataka do kojih će doći i koje će dostaviti nadležnim tijelima svoje države biti veća od eventualnih ugovornih sankcija u slučaju da Austrija uopće sazna za njihovo kršenje.

Slijedom navedenog, smatram da Sud EU-a u konkretnom slučaju nije u dovoljnoj mjeri zaštitio nacionalnu sigurnost Austrije.

\subsection{Faza konačnog obračuna Suda EU-a s nacionalnim sigurnostima država članica}

Slijedom spomenute presude Tele $2 i$ Watson, sudovi čak triju država članica, Ujedinjenoga Kraljevstva, Belgije i Francuske, postavili su prethodna pitanja Sudu EU-a.

Nadležni sud Ujedinjenoga Kraljevstva postavio je pitanje ubraja li se nacionalno zakonodavstvo koje omogućava vlastima da zahtijevaju od ope-

${ }^{53}$ Europska komisija protiv Republike Austrije, para 92. i 93. 
ratora sveobuhvatni i kolektivni prijenos podataka sigurnosnim službama sa svrhom zaštite nacionalne sigurnosti u doseg prava Europske unije te ako da, je li takvo zakonodavstvo protivno pravu Europske unije, konkretno Direktivi o privatnosti i elektroničkim komunikacijama kako je izmijenjena Direktivom o zadržavanju podataka. ${ }^{54}$

Sud je na oba pitanja odgovorio potvrdno. U vezi s prvim pitanjem odbio je argument da nacionalna sigurnost ne ulazi u doseg prava Europske unije u skladu s trećom rečenicom čl. 4/2. UEU-a. Ponavljajući zaključak iz presude ZZ, istaknuo je da činjenica da se neka odluka tiče nacionalne sigurnosti države članice ne dovodi sama po sebi do neprimjene prava Europske unije, odnosno ne znači da takva odluka može biti protivna tom pravu. ${ }^{55}$ Isto je ponovio i u spojenome belgijskom i francuskom predmetu La Quadrature du Net. ${ }^{56}$ Protivno pravu Europske unije, prema shvaćanju Suda EU-a, nacionalno zakonodavstvo svakako omogućava javnim vlastima da zahtijevaju od operatora sveobuhvatno i kolektivno zadržavanje i prijenos podataka sigurnosnim službama sa svrhom zaštite nacionalne sigurnosti. ${ }^{57}$ Sveobuhvatno i kolektivno zadržavanje podataka dopušteno je tek kada je država članica suočena sa stvarnom i aktualnom ili bar predvidivom prijetnjom za nacionalnu sigurnost, uz obvezu da je takva odluka podložna nadzoru neovisnoga sudskog ili upravnog tijela. ${ }^{58} \mathrm{Na}$ nepredvidivost prijetnji nacionalnoj sigurnosti, kao i činjenicu neučinkovitosti zadržavanja podataka tek kad prijetnja nacionalnoj sigurnosti bude identificirana, Sud EU-a nije se posebno osvrtao.

Na taj je način Sud EU-a nacionalnu sigurnost neposredno podvrgnuo testu proporcionalnosti, no, koristeći se Rodinovim rječnikom, svrstao ju je među male slučajeve nacionalnog identiteta (Rodin, 2011, str. 39), odnosno izjednačio je s Besselinkovim „trivijalnim odredbama ustavnog prava“ (Besselink, 2010, str. 49).

Prema tekstu UEU-a, situacija je upravo suprotna. Treća rečenica čl, 4/2. UEU-a, ističući važnost nacionalne sigurnosti pojedine države članice te

${ }^{54}$ Presuda od 6. 10. 2020., Privacy International protiv Secretary of State for Foreign and Commonwealth Affairs i ostalih, C-623/17, ECLI:EU:C:2020:790 (Privacy International), para 30. i 50.

55 Privacy International, para 44. i 49.

56 Presuda od 6. 10. 2020., La Quadrature du Net i ostali protiv Premier ministre i ostalih $i$ Ordre des barreaux francophones et germanophone i ostali protiv Conseil des ministres, C-511/18, C-512/18 i C-520/18, ECLI:EU:C:2020:791 (La Quadrature du Net), para 99. i 104.

57 Privacy International, para 82., i La Quadrature du Net, para 134. - 139.

58 La Quadrature du Net, para 137. 
njezin položaj u kontekstu prijenosa ovlasti s država članica na Europsku uniju, sadržava prilog "posebice“.

Člankom 31/1. Bečke konvencije o pravu međunarodnih ugovora (dalje u tekstu: Bečka konvencija) ${ }^{59}$ propisano je kako se Ugovor mora tumačiti u dobroj vjeri, prema uobičajenom smislu izraza iz ugovora u njihovu kontekstu i u svjetlu predmeta i svrhe ugovora (Crnić-Grotić, 2002, str. 116). Dakle, „uobičajeni smisao izraza“ temelj je svake interpretacije teksta (Beck, 2016, str. 491). To je pravilo u praksi ponavljao i Sud EU-a. ${ }^{60}$ Napomenimo, iako se Bečka konvencija u skladu s čl. 1. ne primjenjuje na Europsku uniju, ona se u skladu s čl. 5. iste Konvencije primjenjuje na Lisabonski ugovor, odnosno UEU i UFEU. ${ }^{61}$

Imajući na umu uobičajen smisao izraza „posebice“ iz treće rečenice čl. 4/2. UEU-a, sve navedeno za aspekte nacionalnog identiteta koji imaju prednost pred pravom EU-a za nacionalnu sigurnost vrijedi više nego za bilo što drugo.

Njemački Ustavni sud naveo je da kada je riječ o ustavnom, odnosno nacionalnom identitetu država članica, njihov „ustavni identitet u analizi proporcionalnosti ne može biti izložen balansiranju kao puki legitimni cilj koji se mora praktično usklađivati s pravima koja jamči pravo EU-a (Horvat Vuković, 2019, str. 259). ${ }^{62}$ U skladu s navedenim, to posebice vrijedi za nacionalnu sigurnost.

Države članice i prije su štitile nacionalnu sigurnost na temelju navedene odredbe (Faraguna, 2016, str. 571). ${ }^{63}$ Zadiranje u zakonodavstvo koje

59 Bečka konvencija o pravu međunarodnih ugovora, NN - Međunarodni ugovori $16 / 93,9 / 08$

${ }^{60}$ V. npr. predmet od 20. 11. 2001., Aldona Malgorzata Jany $i$ ostali v Staatssecretaris van Justitie, C-268/99, ECLI:EU:C:2001:616, para 35., ili predmet od 2. 3. 1999., Nour Eddline El-Yassini v Secretary of State for Home Department, C-416/96, ECLI:EU:C:1999:107, para 47., i praksu navedenu u tim predmetima.

${ }^{61} \mathrm{U}$ tom smislu vidi npr. predmet od 25. 2. 2010., Firma Brita GmbH protiv Hauptzollamt Hamburg-Hafen C-386/08, ECLI:EU:C:2010:91, para 42., predmet od 16. 6. 1998., A. Racke GmbH \& Co. protiv Hauptzollamt Mainz, C-162/96 ECLI:EU:C:1998:293, para 49., ili Mišljenje od 4. 12. 2018. Andy Wightman i dr. protiv Secretary of State for Exiting the European Union, C-621/18 ECLI:EU:C:2018:978, para 79. S druge strane, u predmetu od 25. 10. 2007., SP SpA i ostali protiv Komisije Europskih zajednica, T-27/03, ECLI:EU:T:2007:317, para 58., Sud EU-a protivi se pozivanju na određene članke Bečke konvencije, naglašavajući sui generis prirodu pravnog poretka tadašnje Zajednice.

62 V. presudu njemačkog Ustavnog suda 2 BvR 2728/13, 2729/13, 2730/13, 2731/13 i 13/13 od 14. siječnja 2014., par. 29.

${ }^{63} \mathrm{Na}$ ovom mjestu navode se primjeri obrazloženih mišljenja nizozemskog i švedskog parlamenta: https://secure.ipex.eu/IPEXL-WEB/scrutiny/COD20110242/nleer.do i https:// 
uređuje sustav nacionalne sigurnosti pojedine države članice nikako nije nešto na što su države članice pristale niti je nešto na što mogu i smiju pristati. Kako je prikazano u drugom poglavlju, države same određuju njezine ciljeve, sastavne dijelove i načine njezine zaštite. Slijedom navedenog, takva je odluka Suda EU-a ultra vires s obzirom na to da je suprotna i čl. 4/1. UEU-a te u svakom smislu oduzima svaki učinak trećoj rečenici čl. 4/2. UEU-a. ${ }^{64}$

Tom presudom Sud EU-a nastavio je proces odvajanja od prakse ESLJP-a (Christakis, 2018; Celeste, 2019, str. 156). Naime, ni ESLJP nije smatrao da pozivanje na nacionalnu sigurnost države članice može tu državu članicu osloboditi svih njezinih obveza u smislu obveze poštivanja ljudskih prava i temeljnih sloboda. Međutim, ESLJP je bio svjestan važnosti potrebe da nacionalna sigurnost ostane $u$ domeni svake države, odnosno u granicama njezine prosudbe. ${ }^{65}$ Imajući u vidu nepredvidivost prijetnji za nacionalnu sigurnost (Celeste, 2019, str. 152), pogotovo u kontekstu sve bržeg razvoja sofisticiranih tehnoloških i komunikacijskih sredstava, ESLJP od tog stava nije odstupio ni kada je riječ bila o zadržavanju podataka. ${ }^{66}$ Naravno, strogo ocjenjujući zakonodavstvo države članice u svakome konkretnom slučaju, ESLJP je ponovno naglasio da se javna vlast može iznimno miješati u pravo pojedinca na poštivanje privatnog života radi interesa nacionalne sigurnosti u skladu sa zakonom i ako je to nužno u demokratskom društvu (v. i Salaj, 2017). ${ }^{67}$

Po uzoru na praksu ESLJP-a, Sud EU-a pitanje nacionalne sigurnosti trebao je ostaviti u odgovornosti država članica kako je i propisano UEU-om, postavljajući odgovarajuće uvjete koje konkretno zakonodavstvo mora za-

secure.ipex.eu/IPEXL-WEB/scrutiny/COD20110242/serik.do o prijedlogu Uredbe o izmjeni Uredbe o privremenom ponovnom uvođenju granične kontrole u iznimnim okolnostima https://eur-lex.europa.eu/legal-content/HR/TXT/?uri=CELEX\%3A52011PC0560.

64 Privacy International, para 33.

65 Vidi npr. Klass $i$ ostali protiv Njemačke, predmet br. 5029/71 od 6. 9. 1978., para 48. i 49., Weber i Saravia protiv Njemačke, br. 54934/00 od 29. 6. 2006., para 106., Kennedy protiv Ujedinjenog Kraljevstva, br. 26839/05 od 18. 5. 2010., para 154., Roman Zakharov protiv Rusije, br. $47143 / 06$ od 4. 12. 2015., para 232. Chahal protiv Ujedinjenog Kraljevstva, br. 22414/93 od 15. 11. 1996., para 131., A i ostali protiv Ujedinjenog Kraljevstva, br. 3455/05 od 19. 2. 2009., para 210.

${ }^{66}$ Centrum for rattvisa protiv Švedske, predmet $35252 / 08$ od 19. 6. 2018. (dalje u tekstu: Centrum), para 112. i 113., Big Brother Watch i ostali protiv Ujedinjenog Kraljevstva, para predmeti 58170/13, 62322/14 i 24960/15 od 13. 9. 2018. (dalje u tekstu: Big Brother), para 320. i dalje.

${ }^{67}$ Centrum, para 103. i 104., Big Brother, para 307. i 308. 
dovoljavati, a ne ga a priori proglašavati suprotnim pravu Europske unije. U slučaju sumnje u konkretnu zlouporabu odredbe treće rečenice čl. 4/2. UEU-a, Europskoj uniji na raspolaganju stoje mehanizmi iz čl. 258. i 260. UFEU-a, a u konačnici i mehanizam iz čl. 7. UEU-a.

\section{Zaključak}

Praksa Suda EU-a nije pratila normativnu izdvojenost koncepta nacionalne sigurnosti u odnosu na pravo Europske unije. Naime, sama normativna izdvojenost tog koncepta iz pravnog sustava Europske unije ne znači i njegovu potpunu izoliranost od tog sustava s obzirom na to da se područja pokrivena pravom Europske unije često poklapaju s područjem nacionalne sigurnosti. Dakle, područje koje uređuje pravo Europske unije često će kolidirati s konceptom nacionalne sigurnosti. U nekim slučajevima ta je kolizija bila manje, a u nekima više očita. Tako se Sud EU-a tim pitanjem bavio u odnosu na zaštitu podataka koje su države članice klasificirale odgovarajućim stupnjem tajnosti u skladu s vlastitim zakonodavstvom, balansirajući interese nacionalnih sigurnosti država članica s jedne strane te prava osoba prema kojima su primijenjene sankcije na temelju upravo tih podataka s druge. Važan je zaključak Suda EU-a u takvim slučajevima bio da činjenica da se neka odluka tiče državne sigurnosti države članice ne dovodi sama po sebi do neprimjene prava Europske unije. Naposljetku, Sud EU-a u pravilu je ostavljao nacionalnim sudovima da provedu balansiranje u svakome pojedinom slučaju.

I u slučajevima gdje su pitanja nacionalne sigurnosti izravno bila u sukobu s pravom Europske unije, Sud EU-a primjenjivao je načelo proporcionalnosti postupkom balansiranja te donekle uzimao u obzir interese nacionalne sigurnosti iako se, primjerice, predmet Europska komisija protiv Republike Austrije nikako ne bi mogao smatrati primjerom uspješna balansiranja.

Presuda Tele2 $i$ Watson otvorila je Pandorinu kutiju kada je riječ o toj problematici. Kada je Sud EU-a utvrdio da nacionalna pravila koja pružateljima elektroničkih komunikacijskih usluga nameću opću obvezu zadržavanja podataka i koja propisuju pristup nadležnih nacionalnih tijela zadržanim podacima nisu u skladu s pravom Europske unije, bilo je tek pitanje vremena kad će se postaviti pitanje svih pitanja u kontekstu ovog rada. To pitanje postavilo se u presudama Privacy International i La Quadrature du Net, a odnosilo se na potrebe sigurnosnih služba država članica 
u kontekstu provođenja mjera utvrđenih nacionalnim zakonodavstvima koja uređuju njihove sustave nacionalne sigurnosti.

Odgovarajući da nacionalno zakonodavstvo koje omogućava vlastima da zahtijevaju od operatora sveobuhvatni i kolektivni prijenos podataka sigurnosnim službama sa svrhom zaštite nacionalne sigurnosti nije u skladu s pravom Europske unije, Sud EU-a izravno je zahvatio u postupanja sigurnosnih služba poduzetih radi zaštite nacionalne sigurnosti. Na taj je način državama članicama praktički onemogućio učinkovito izvršavanje njihovih obveza u vezi s očuvanjem nacionalne sigurnosti. ${ }^{68}$

Kako je navela Austrija u predmetu Europska komisija protiv Republike Austrije, sigurnosna politika svake države bitan je element njezina državnog suvereniteta te je na državama članicama da definiraju svoje osnovne interese sigurnosti. To je iskazano i u čl. 4/2. UEU-a koji nacionalnu sigurnost posebice ostavlja u isključivoj odgovornosti svake države članice.

Umjesto da se vodio praksom ESLJP-a i postavio određene uvjete nacionalnim zakonodavstvima koja uređuju prikupljanje podataka i postupanja sigurnosnih služba, Sud EU-a presudama Privacy International i La Quadrature du Net lišio je učinka treću rečenicu čl. 4/2. UEU-a.

\section{Popis literature}

Beck, G. (2016). The macro level: The structural impact of general international law on EU Law. The Court of Justice of the EU and the Vienna Convention on the Law of Treaties. Yearbook of European Law, 35(1), 484-512, https://doi. org/10.1093/yel/yew018.

Besselink, L. F. M. (2010). National and constitutional identity before and after Lisbon. Utrecht Law Review, 6(3), 36-49, https://doi.org/10.18352/ulr.139.

Celeste, E. (2019). The Court of Justice and the ban on bulk data retention: Expansive potential and future scenarios. European Constitutional Law Review, 15(1), 134-157, https://doi.org/10.1017/s1574019619000038.

Christakis, T. (2018). A fragmentation of EU/ECHR law on mass surveillance: initial thoughts on the Big Brother Watch judgment. Dostupno na https:/europeanlawblog.eu/2018/09/20/a-fragmentation-of-eu-echr-law-on-mass-surveillance-initial-thoughts-on-the-big-brother-watch-judgment/, https://doi. org/10.5040/9781474202046.ch-007.

Cloots, E. (2015). National identity in EU Law. Oxford, United Kingdom: Oxford University Press.

68 Vidi argument Poljske u presudi od 6. 9. 2017., Slovačka Republika i Mađarska protiv Vijeća Europske unije, C-643/15, ECLI:EU:C:2017:631, para 36. 
Crnić-Grotić, V. (2002). Pravo međunarodnib ugovora. Rijeka, Hrvatska: Pravni fakultet Sveučilišta.

Cvrtila, V. (1995). Nacionalni interesi i nacionalna sigurnost. Politička misao, 32(2), 62-69.

Faraguna, P. (2016). Taking constitutional identities away from the courts. Brooklyn Journal of International Law, 41(2), 491-578.

Horvat Vuković, A. (2019). Ustavni sud Republike Hrvatske kao „europski“ sud i očuvanje nacionalnih standarda zaštite temeljnih ljudskih prava i sloboda. Zbornik Pravnog fakulteta u Zagrebu, 69(2), 249-276, https://doi.org/10.3935/ zpfz.69.2.04.

Koutrakos, P. (2016). Public security exceptions and EU free movement law. U P. Koutrakos, N. N. Shuibhne \& P. Syrpis (Eds.), Exceptions from EU free movement law: Derogation, justification and proportionality (190-217). Oxford, UK: Hart Publishing, https://doi.org/10.5040/9781474203067.ch-010.

Lacković, D. (2000). Poteškoće u definiranju pojma nacionalne sigurnosti. Polemos, 2(6), 197-206.

Nobilo, M. (1988). Pojam sigurnosti u terminologiji međunarodnih odnosa. Politička misao, 25(4), 69-80.

Rodin, S. (2011). National identity and market freedoms after the Treaty of Lisbon. Croatian Yearbook of European Law and Policy, 7(1), 11-41, https://doi. org/10.3935/cyelp.07.2011.130.

Salaj, Z. (2017). Međunarodnopravne implikacije masovnog nadzora elektroničkih komunikacija u kontekstu ljudskih prava, s posebnim osvrtom na sigurnosno-obavještajni sustav u Republici Hrvatskoj. Zagrebačka pravna revija, 6(1), 15-40, https://doi.org/10.22182/sp.12019.1.

Stępkowski, L. (2016). National identity of a member state in European union law in the context of relocation of migrants. Review of Comparative Law, 25(2), 103-128.

Tatalović, S. (1997). Nacionalna sigurnost Republike Slovenije. Politička misao, 34(3), 74-102.

Von Danwitz, T. (2014). The rule of law in the recent jurisprudence of the ECJ. Fordham International Law Journal, 37(5) 1311-1347.

\section{Pravni izvori}

Bečka konvencija o pravu međunarodnih ugovora, NN - MU 16/93, 9/08

Direktiva (EU) 2016/680 Europskog parlamenta i Vijeća od 27. travnja 2016. o zaštiti pojedinaca u vezi s obradom osobnih podataka od strane nadležnih tijela u svrhe sprečavanja, istrage, otkrivanja ili progona kaznenih djela ili izvršavanja kaznenih sankcija i o slobodnom kretanju takvih podataka te o stavljanju izvan snage Okvirne odluke Vijeća 2008/977/PUP. Dostupno na https:// eur-lex.europa.eu/legal-content/HR/TXT/?uri=CELEX\%3A32016L0680. 
Direktiva 2013/33/EU od 26. lipnja 2013. Europskog parlamenta i Vijeća o utvrđivanju standarda za prihvat podnositelja zahtjeva za međunarodnu zaštitu. Dostupno na https://eur-lex.europa.eu/legal-content/HR/TXT/HTML/?uri=C ELEX:32013L0033\&from=EN.

Direktiva Vijeća 2000/78/EZ od 27. studenoga 2000. o uspostavi općeg okvira za jednako postupanje pri zapošljavanju i obavljanju zanimanja. Dostupno na https://eur-lex.europa.eu/legal-content/HR/TXT/PDF/?uri=CELEX:32000L0 $078 \&$ from $=\mathrm{EN}$.

Direktiva Vijeća 2004/83/EZ od 29. travnja 2004. o minimalnim standardima za kvalifikaciju i status državljana treće zemlje ili osoba bez državljanstva kao izbjeglica ili osoba kojima je na drugi način potrebna međunarodna zaštita te o sadržaju odobrene zaštite. Dostupno na https://eur-lex.europa.eu/legalcontent/HR/TXT/?uri=CELEX\%3A32004L0083.

Direktiva Vijeća 2004/83/EZ od 29. travnja 2004. o minimalnim standardima za kvalifikaciju i status državljana treće zemlje ili osoba bez državljanstva kao izbjeglica ili osoba kojima je na drugi način potrebna međunarodna zaštita te o sadržaju odobrene zaštite. Dostupno na https://eur-lex.europa.eu/legalcontent/HR/TXT/?uri=CELEX\%3A32004L0083.

Direktiva 2000/31/EZ Europskog parlamenta i Vijeća od 8. lipnja 2000. o određenim pravnim aspektima usluga informacijskog društva na unutarnjem tržištu, posebno elektroničke trgovine

Direktiva 2002/58/EZ Europskog parlamenta i Vijeća od 12. srpnja 2002. o obradi osobnih podataka i zaštiti privatnosti u području elektroničkih komunikacija. Dostupno na https://eur-lex.europa.eu/legal-content/HR/ TXT/?uri=celex\%3A32002L0058.

Direktiva 2006/24/EZ Europskog parlamenta i Vijeća od 15. ožujka 2006. o zadržavanju podataka dobivenih ili obrađenih u vezi s pružanjem javno dostupnih elektroničkih komunikacijskih usluga ili javnih komunikacijskih mreža i o izmjeni Direktive 2002/58/EZ. Dostupno na https://eur-lex.europa.eu/legalcontent/HR/TXT/?uri=celex\%3A32006L0024.

Direktiva 2008/115/EZ Europskog parlamenta i Vijeća od 16. prosinca 2008. o zajedničkim standardima i postupcima država članica za vraćanje državljana trećih zemalja s nezakonitim boravkom. Dostupno na https://eur-lex.europa. eu/legal-content/HR/TXT/?uri=CELEX\%3A32008L0115.

European Parliament, Directorate General for internal policies, Policy Department C: Citizens' Rights adn Constitutional Affairs: „National security and secret evidence in legislation and before the courts: exploring the challenges", Study for the LIBE Commitee, 10. 12. 2014. Dostupno na https://www.ceps. eu/ceps-publications/national-security-and-secret-evidence-legislation-andcourts-exploring-challenges/.

Law number 3649, National Intelligence Service and other provisions od 3. 3. 2008. Dostupno na http://www.nis.gr/npimages/docs/LAW_NUMBER\%20 3649_en.pdf.

Ley 36/2015, de 28 de septiembre, de Seguridad National. Dostupno na https:// www.boe.es/buscar/doc.php?id=BOE-A-2015-10389. 
Obrazloženo mišljenje nizozemskog parlamenta o prijedlogu Uredbe 562/2006. Dostupno na https://secure.ipex.eu/IPEXL-WEB/scrutiny/COD20110242/ nleer.do.

Obrazloženo mišljenje švedskog parlamenta o prijedlogu Uredbe 562/2006. Dostupno na https://secure.ipex.eu/IPEXL-WEB/scrutiny/COD20110242/serik. do.

Pročišćene verzije Ugovora o Europskoj uniji i Ugovora o funkcioniranju Europske unije. Dostupno na https://eur-lex.europa.eu/legal-content/HR/ TXT/?uri=CELEX\%3A12016ME\%2FTXT.

Republic of Lithuania Law on the basics of national security of Lithuania. Dostupno na https://e-seimas.lrs.lt/portal/legalAct/lt/TAD/TAIS.120108?jfwid=nz8qn8i8i.

Sud EU-a, Priopćenje za medije 145/16 od 21. 12. 2016. Dostupno na https:// curia.europa.eu/jcms/upload/docs/application/pdf/2016-12/cp160145hr.pdf. Vidi Tele2 $i$ Watson, para 62. i 114.

The Law No.51/July 29,1991 on the National Security of Romania. Dostupno na https://www.sri.ro/fisiere/legislation/Law_national-security.pdf.

Uredba 2016/679 Europskog parlamenta i Vijeća od 27. travnja 2016. o zaštiti pojedinaca u vezi s obradom osobnih podataka i o slobodnom kretanju takvih podataka te o stavljanju izvan snage Direktive 95/46/EZ. Dostupno na https://eur-lex.europa.eu/legal-content/HR/TXT/?uri=celex\%3A32016R0679, https://doi.org/10.36506/av.63.1.

Zakon o sigurnosno-obavještajnom sustavu Republike Hrvatske, NN 79/06, $105 / 06$.

\section{Sudska praksa}

Mišljenje,EuropskakomisijaprotivRepublikeAustrije, C-187/16,ECLI:EU:C:2017:578, 20. 7. 2017.

Mišljenje, Andy Wightman i dr. protiv Secretary of State for Exiting the European Union, C-621/18 ECLI:EU:C:2018:978, 4. 12. 2018, https://doi.org/10.1093/ he/9780191896668.003.0045

Predmet ESLJP-a, A i ostali protiv Ujedinjenog Kraljevstva, br. 3455/05, 19. 2. 2009. Predmet ESLJP-a, Kennedy protiv Ujedinjenog Kraljevstva, br. 26839/05, 18. 5. 2010.

Predmet ESLJP-a, Roman Zakharov protiv Rusije, br. 47143/06, 4. 12. 2015.

Predmet ESLJP-a, Weber i Saravia protiv Njemačke, br. 54934/00, 29. 6. 2006.

Predmet ESLJP-a, Big Brother Watch $i$ ostali protiv Ujedinjenog Kraljevstva, br. 58170/13, 62322/14 i 24960/15, 13. 9. 2018.

Predmet ESLJP-a, Centrum for rattvisa protiv Švedske, br. 35252/08, 19. 6. 2018.

Predmet ESLJP-a, Chabal protiv Ujedinjenog Kraljevstva [VV], br. 22414/93, 15. 11. 1996.

Predmet ESLJP-a, Klass i ostali protiv Njemačke, br. 5029/71, 6. 9. 1978. 
Presuda njemačkog Ustavnog suda, 2 BvR 2728/13, 2729/13, 2730/13, 2731/13 i 13/13, 14. siječnja 2014.

Presuda Suda Europske unije, A. Racke GmbH \& Co. protiv Hauptzollamt Mainz, C-162/96 ECLI:EU:C:1998:293, 16. 6. 1998.

Presuda Suda Europske unije, Aldona Malgorzata Jany $i$ ostali v Staatssecretaris van Justitie, C-268/99, ECLI:EU:C:2001:616, 20. 11. 2001.

Presuda Suda Europske unije, Alexander Dory protiv Bundesrepublik Deutschland, C-186/01, ECLI:EU:C:2003:146, 11. 3. 2003.

Presuda Suda Europske unije, Carmelo Angelo Bonsignore v. Oberstadtdirektor der Stadt Köln, C-67/74, ECLI: ECLI:EU:C:1975:34, 26. 2. 1975.

Presuda Suda Europske unije, Digital Rights Ireland Ltd protiv Minister for Communications, Marine and Natural Resources $i d r$. i Kärntner Landesregierung $i$ dr., C-293/12 i C-594/12, ECLI:EU:C:2014:238, 8.4.2014., https://doi. org/10.1093/he/9780191847288.003.0007

Presuda Suda Europske unije, Ellinika Nafpigeia AE protiv Europska komisija, C-246/12 P, ECLI:EU:C:2013:133, 28. 3. 2013.

Presuda Suda Europske unije, Europska komisija idr. protiv Yassin Abdullab Kadi, spojeni predmeti C-584/10 P, C-593/10 P i C-595/10 P, ECLI:EU:C:2013:518, 18. 7. 2013.

Presuda Suda Europske unije, Europska komisija protiv Helenske Republike, C-93/17, ECLI:EU:C:2018:903, 14. 11. 2018.

Presuda Suda Europske unije, Europska komisija protiv Helenske Republike, C-93/17, ECLI:EU:C:2018:903, 14. 11. 2018.

Presuda Suda Europske unije, Europska komisija protiv Republike Austrije, C-187/16, ECLI:EU:C:2018:194, 20. 3. 2018.

Presuda Suda Europske unije, Firma Brita GmbH protiv Hauptzollamt HamburgHafen, C-386/08, ECLI:EU:C:2010:91, 25. 2. 2010.

Presuda Suda Europske unije, Gennaro Cafaro protiv DQ, C-396/18, ECLI:EU:C:2019:929, 7. 11. 2019.

Presuda Suda Europske unije, H. T. protiv Land Baden-Württemberg, C-373/13, ECLI:EU:C:2015:413, 24. 6. 2015.

Presuda Suda Europske unije, Ilonka Sayn-Wittgenstein protiv Landeshauptmann von Wien, C-208/09, ECLI:EU:C:2010:806, 22. 12. 2010.

Presuda Suda Europske unije, J. N. protiv Staatssecretaris van Veiligheid en Justitie, C-601/15, ECLI:EU:C:2016:84, 15. 2. 2016.

Presuda Suda Europske unije, Janko Rottman protiv Freistaat Bayern, C-135/08, ECLI:EU:C:2010:104, 2. 3. 2010.

Presuda Suda Europske unije, Komisija Europskih zajednica protiv Talijanske Republike, C-337/05, ECLI:EU:C:2008:203, 8. 4. 2008.

Presuda Suda Europske unije, La Quadrature du Net i ostali protiv Premier ministre $i$ ostalib $i$ Ordre des barreaux francophones et germanophone $i$ ostali protiv Conseil des ministres, C-511/18, C-512/18 i C-520/18, ECLI:EU:C:2020:791, 6. 10. 2020. 
Presuda Suda Europske unije, Land Baden-Württemberg v. Panagiotis Tsakouridis, C-145/09, EU:C:2010:708, 23. 11. 2010.

Presuda Suda Europske unije, Ministre de l'Intérieur protiv Aitor Oteiza Olazabal, C-100/01, ECLI:EU:C:2002:712, 26. 11. 2002.

Presuda Suda Europske unije, Nabiel Peter Bogendorff von Wolffersdorff protiv Standesamt der Stadt Karlsrube i Zentraler Juristischer Dienst der Stadt Karlsruhe, C-438/14, ECLI:EU:C:2016:401, 2. 6. 2014., https://doi.org/10.2139/ ssrn. 2757609

Presuda Suda Europske unije, Nour Eddline El-Yassini v Secretary of State for Home Department, C-416/96, ECLI:EU:C:1999:107, 2. 3. 1999.

Presuda Suda Europske unije, Organisation des Modjabedines du people d'Iran protiv Vijeća Europske unije, T-228/02 ECLI:EU:T:2006:384, 12. 12. 2006.

Presuda Suda Europske unije, Privacy International protiv Secretary of State for Foreign and Commonwealth Affairs $i$ ostalih, C-623/17, ECLI:EU:C:2020:790, 6. 10. 2020.

Presuda Suda Europske unije, Slovačka Republika i Mađarska protiv Vijeća Europske unije, C-643/15, ECLI:EU:C:2017:631, 6. 9. 2017.

Presuda Suda Europske unije, SP SpA i ostali protiv Komisije Europskih zajednica, T-27/03, ECLI:EU:T:2007:317, 25. 10. 2007.

Presuda Suda Europske unije, Tele2 Sverige AB protiv Post-och telestyrelsen i Secretary of State for the Home Department protiv Toma Watsona, Petera Bricea $i$ Geoffreyja Lewisa, C-203/15 i 698/15, ECLI:EU:C:2016:970, 21. 12. 2016.

Presuda Suda Europske unije, Vlada Communauté française $i$ Gouvernement wallon protiv Gouvernement flamand, C-212/06, ECLI:EU:C:2008:178., 1. 4. 2008.

Presuda Suda Europske unije, Yassin Abdullab Kadi protiv Europske komisije, T-85/09, ECLI:EU:T:2010:418, 30. 9. 2010.

Presuda Suda Europske unije, Yvonne van Duyn v. Home Office C-41/74, ECLI: ECLI:EU:C:1974:133, 4. 12. 1974.

Presuda Suda Europske unije, ZZ protiv Secretary of State for the Home Department, C-300/11 ECLI:EU:C:2013:363, 4. 6. 2013.

Presuda Suda Europske unije, Malgožata Runevič-Vardyn i Eukasz Pawet Wardyn protiv Vilniaus miesto savivaldybes administracija i dr., C-391/09, ECLI:EU:C:2011:291, 12. 5. 2011. 


\section{MEMBER STATES' SECURITY SENSITIVE DATA IN THE CASE LAW OF THE COURT OF JUSTICE OF THE EUROPEAN UNION}

\section{Summary}

The protection of national security aspects is inberent to the EU member states. The case law of the CJEU was not in line with the normative detachment of the concept of national security relating to EU law. The CJEU bas dealt with that concept both indirectly and directly by performing a balancing test between national security interests of member states and freedom and rights guaranteed by EU law. According to its case law, the mere fact that a question concerns a member state's national security cannot result in EU law being inapplicable. The CJEU's latest case law has encroached the powers conferred upon it by the EU treaties and deprived Article 4 Paragraph 2 of the TEU of its effet utile. Instead of defining necessary conditions for national security services in data retention context, which would have harmonized their actions with EU law, looking up to the ECHR as a role model, the CJEU has virtually prevented member states from exercising their obligations regarding national security protection.

Keywords: national security, national law, Article 4/2 TEU, the CJEU case law, data retention 